Arq. Bras. Med. Vet. Zootec., v.61, n.4, p.791-796, 2009

\title{
T lymphocyte subsets of the umbilical cord blood of dogs
}

[Subpopulações de linfócitos t no sangue de cordão umbilical de cães]

\author{
M.L.B. Cápua ${ }^{1}$, A.E. Santana ${ }^{2}$, A.P.M. Nakage ${ }^{3}$, A.V. Godoy ${ }^{1}$, A. Kataoka ${ }^{4}$ \\ ${ }^{1}$ Aluno de pós-graduação - FCAV-UNESP - Jaboticabal, SP \\ ${ }^{2}$ Faculdade de Ciências Agrárias e Veterinárias - UNESP - Jaboticabal, SP \\ ${ }^{3}$ Centro Universitário Barão de Mauá - Ribeirão Preto, SP \\ ${ }^{4}$ Unicastelo - Fernandópolis, SP
}

\begin{abstract}
The hematological parameters red blood cells (RBC) and total white blood cells (WBC) counts, hematocrit, hemoglobin concentration, and RBC indexes (median corpuscular volume and median corpuscular hemoglobin concentration) were determined and $\mathrm{T} \mathrm{CD}^{+}$lymphocytes and $\mathrm{CD} 4^{+}$and $\mathrm{CD} 8^{+}$subpopulations of the umbilical cord blood (UCB) of dogs were quantified by the cytofluorimetric technique. Nine adult Beagles, from two do five-year old, were used as control. The umbilical cord blood (UCB) was collected from 20 neonate dogs. The method for the UCB collection was adequate to obtain sufficient quantity of blood for the accomplishment of the hematological analyses and lymphocyte quantification. Cytoscopic preparations of the UCB suggested high erythropoietic activity. There was no difference for the global leukocyte and lymphocyte counts between the groups. UCB T lymphocyte counts were lower than those obtained for adult dogs. The proportion of CD4:CD8 showed a great dominance of $\mathrm{T} \mathrm{CD} 4^{+}$cells over $\mathrm{T} \mathrm{CD} 8^{+}$lymphocytes in $\mathrm{UCB}$.
\end{abstract}

Keywords: dog, immunophenotyping, hematology, lymphocyte subpopulations, umbilical cord blood

\section{RESUMO}

Determinaram-se os valores hematológicos da contagem de hemácias, contagem total de leucócitos, hematócrito, concentração de hemoglobina e os indices hematimétricos (volume corpuscular médio e concentração de hemoglobina corpuscular média) e quantificaram-se os linfócitos $T C D 5^{+}$e as subpopulações $C D 4^{+}$e CD8 $8^{+}$do sangue do cordão umbilical (SCU) de cães por meio da técnica de citometria de fluxo. Nove cães adultos, da raça Beagle, foram utilizados como controle. O SCU foi colhido de 20 cães neonatos, a termo. $O$ método de colheita de SCU utilizado proporcionou quantidade suficiente de sangue para realização das análises hematológicas e quantificação de linfócitos. As preparações citoscópicas do SCU sugeriram elevada atividade eritropoética. Não houve diferença nas contagens globais de leucócitos e linfócitos entre os grupos. A contagem de linfócitos $T$ no SCU foi mais baixa que a obtida em animais adultos. A proporção CD4:CD8 obtida demonstrou a grande dominância das células $T C D 4^{+}$sobre os linfócitos $T C D 8^{+}$no SCU canino.

Palavras-chave: cão, imunofenotipagem, hematologia, subpopulações linfocitárias, sangue do cordão umbilical

\section{INTRODUCTION}

The umbilical cord blood (UCB) is a rich source of stem cells with high capacity of selfrenovation and proliferation (Dimitriou et al., 1998). The umbilical cord blood transplants lead to few or none occurrences of the graft-versushost disease (GVHD), when compared to bone marrow transplants; a fact that is probably related to the functional immaturity of the UCB T cells (Lu et al., 1996; Lin and Chao, 2001).

The numbers and tintorial characteristics of the UCB lymphocytes differ from those of the peripheral blood in human beings (Lin and Chao, 2001). The functions of $T$ cells present in the $\mathrm{UCB}$, such as the ability to produce cytokines (Robinson et al., 2002), activities of auxiliary $\mathrm{T}$

Recebido em 10 de janeiro de 2009

Aceito em 9 de julho de 2009

E-mail: marialuisa_capua@yahoo.com.br 
cells, and the expression of surface antigens and receptors are reduced when compared to those of adult T cells (Lu et al., 1996).

The immunophenotyping of lymphocytes can be easily obtained by the flow cytometry (Byrne et al., 2000). In human immune-hematology, many authors have quantified lymphocytes and its different subpopulations in the UCB, using the immunophenotyping and cytofluorimetric reading (Dimitriou et al., 1998; Motley et al., 1996; Szabolcs et al., 2003).

Researches have revealed that there is a lower quantity of T CD3, CD4 and CD8 lymphocytes in the human UCB, when compared to the adult peripheral blood, as well as a higher proportion of CD4:CD8 (Dimitriou et al., 1998; Motley et al., 1996). It has also been reported a high quantity of immature cells, not only among the $\mathrm{T}$ lymphocyte subpopulations, but among B lymphocytes (Szabolcs et al., 2003), in addition to some populations not found in adults peripheral blood, or found in few numbers, like $\mathrm{CD} 19^{+} 10^{+}$and $\mathrm{CD}^{+} 3^{-}$cells (Motley et al., 1996).

In veterinary medicine, the flow cytometry technique has been used to evaluate the progression of viral infections such as the feline immunodeficiency and the feline leukemia, responses to organ transplants on canine models and responses to immune infections (Byrne et al., 2000).

Some studies make reference to the lymphocyte immunophenotyping of the peripheral blood of dogs (Byrne et al., 2000; Faldyna et al., 2001; HogenEsch et al., 2004; Kataoka, 2005). Such studies have demonstrated that the percentage of $\mathrm{T}$ CD8 cells raises gradually with age, in a way that the proportion CD4:CD8 decreases (Faldyna et al., 2001; HogenEsch et al., 2004).

Literature is scarce in relation to canine UCB. There are reports about the hematological values, including the reticulocytes counts, on which the quantity found in the UCB has presented to be higher that that from the peripheral blood of neonate and adult dogs (Nakage, 2002, 2003). There are also reports on the influence of the type of parturition over the hematological values (Nakage, 2005). However, no bibliographic reports were found about the immunophenotypic characteristics lymphocytic cells from canine UCB.

The present trial of quantification of pan-T lymphocytic cells and CD4 and CD8 subpopulations in the umbilical cord blood of neonate dogs was made by the use of surface markers (monoclonal antibodies). It had the aim of providing new information on the cellular composition of the umbilical cord blood of dogs, and compare it to the values obtained for adult dogs.

\section{MATERIAL AND METHODS}

The umbilical cord blood was collected from 20 fully developed neonates of different breeds, with a median gestation time of 58 days. The neonates were client-owned and derived from healthy females dogs presented for cesarian or vaginal deliveries.

After removal of the placenta, the blood was collected by puncture of the umbilical vessels in the juxtaplacental section of the placenta with a $5 \mathrm{~mL}$-syringe containing $1 \mathrm{mg} \mathrm{Na}_{2} \mathrm{EDTA} / \mathrm{mL}$ of blood.

The control group was formed by nine healthy adult male Beagles (two to five-year old). The peripheral blood was collected by puncture of the jugular with a 5mL-syringe containing $1 \mathrm{mg}$ $\mathrm{Na}_{2}$ EDTA $/ \mathrm{mL}$ of blood.

Immediately after collection, the umbilical cord blood and the peripheral blood were submitted to laboratory analyses, including red blood cells (RBC) and total white blood cells (WBC) counts, hematocrit (HCT), hemoglobin (Hgb) concentration, and the RBC indexes median corpuscular volume (MCV) and median corpuscular hemoglobin concentration (MCHC), using an automatic cell counter ${ }^{1}$. Differential leukocytes counts were done by counting 100 cells on blood smears stained with MayGrunwald Giemsa.

The cytofluorimetric studies were done within a maximum time of 24 hours after collection. For such, aliquots of the umbilical cord blood and peripheral blood were sent to the Laboratório de Citometria de Fluxo at the Fundação Hemocentro in Ribeirão Preto, at the Faculdade de Medicina

${ }^{1}$ ACT-8 Coulter, Beckman Coulter - Fullerton, USA 
de Ribeirão Preto, Universidade de São Paulo. The methodology for the cytometric evaluation consisted, initially, on the identification of three sterile tubes (tube $1-\gamma 1 \mathrm{PE} / \gamma 2 \mathrm{FITC}$, tube 2 CD5FITC/CD4PE, and tube 3CD5FITC/CD8PE). Than, $100 \mu \mathrm{L}$ of UCB were added in each tube and $2 \mu \mathrm{L}$ of the respective reagents: $\gamma 1 \mathrm{PE}^{2}$ and $\gamma 2 \mathrm{FITC}^{2}$ on tube 1 ; anti$\mathrm{CD}^{+}$conjugated with FITC $^{2}$ and anti-CD4 $4^{+}$ conjugated with $\mathrm{PE}^{2}$ on tube 2; anti$\mathrm{CD}^{+}$conjugated with FITC $^{2}$ and anti-CD8 ${ }^{+}$ conjugated with $\mathrm{PE}^{2}$ on tube 3 . The tubes were incubated for 20 minutes under room temperature in the dark.

It was added $1 \mathrm{~mL}$ of red blood cells lysing solution $^{3}$ to each tube, followed by homogenization and addition of $1 \mathrm{~mL}$ of the same reagent. The tubes were then incubated for ten minutes under room temperature in the dark. Afterward, it was made the cell washing with saline solution buffered with $0.01 \mathrm{M}$ phosphate and $\mathrm{pH}$ between 7.4 and 7.6 (PBS), for three times, which consisted on the centrifugation at 1,800 RPM for three minutes, discharge of the float and addition of $2 \mathrm{~mL}$ of PBS. After discharging the float, $200 \mu \mathrm{L}$ PBS were added into the three tubes and the samples were subjected to analyses on the FACS cytofluorometer $^{3}$ for the identification and counting of the T lymphocytary subpopulation.

The statistical analysis was performed using GraphPad Prism ${ }^{\circledR}$ version 3.00 for Windows software. Comparisons between the groups were made using an unpaired $t$-test and a $\mathrm{P}<0.05$ was considered significant. The results were expressed as mean \pm standard error.

\section{RESULTS AND DISCUSSION}

The global counting of red blood cells and the $\mathrm{MCHC}$ obtained for the UCB were inferior to those of the peripheral blood of adult dogs $(\mathrm{P}<0.0001)$ (Table 1). There was no statistical difference between the hematocrit of both groups $(\mathrm{P}=0.96)$, which can be explained by the higher $\mathrm{MCV}$ of the UCB cells $(\mathrm{P}<0.0001)$. Also, no statistical difference was found between the hemoglobin concentration $(\mathrm{P}=0.40)$.
The microscopic preparations of the UCB put in evidence the presence of young macrocytic and hypocromic red blood cells, in addition to a big amount of erythroblasts and red blood cells containing Howell-Jolly bodies, resembling like the peripheral blood of dogs until three-day old, whose erythropoietic activity, generally, is thought to be high (Meinkoth and Clinkenbeard, 2000).

As for the leukometric variables, there was no statistical difference between the global count of leukocytes $(\mathrm{P}=0.9543)$ and the relative $(\mathrm{P}=0.1186)$ and absolute $(\mathrm{P}=0.1548)$ counts of lymphocytes of both groups.

On human immune-hematology, the study of $\mathrm{T}$ cells in the UCB has a considerable importance (Lin and Chao, 2001), in a way that many researches have been conducted to establish the immunophenotypic characteristics of lymphocyte populations and subpopulations in the umbilical cord blood (Dimitriou et al., 1998; Motley et al., 1996; Schultz et al., 2000).

Although there are reports on the immunophenotyping of dogs peripheral blood lymphocytes (Byrne et al., 2000; Faldyna et al., 2001; HogenEsch et al., 2004; Kataoka, 2005) and bone marrow (Faldyna et al., 2003), there is not a study on the immunophenotypic characteristics of lymphocytes of canine UCB.

The mean values obtained for pan-T lymphocyte, $\mathrm{CD}^{+}$and $\mathrm{CD}^{+}$lymphocytes counts in canine UCB were lower than those obtained in the peripheral blood of two to five-year old adult dogs $(\mathrm{P}<0.0001)$ (Table 2).

The results obtained in this trial agree with studies accomplished on human immunehematology, which have reported lower quantities of pan-T cells, T-auxiliary and Tcytotoxic cells in the UCB, compared to those found in the peripheral blood of newly born babies and adults (Motley et al., 1996; Dimitriou et al., 1998; Schultz et al., 2000). However, other researchers found higher quantities of $\mathrm{T}$, NK, and $\mathrm{B}$ cells when compared to the peripheral blood of adults (Szabolcs et al., 2003).

${ }^{2}$ Serotec - Kidlington, UK

${ }^{3}$ Becton Dickinson - San Jose, USA 
Table 1. Erytrogram values (mean \pm SE) for umbilical cord blood from newborn puppies $(n=20)$ and peripheral blood from adult Beagles $(\mathrm{n}=9)$, collected in ethylene diamine tetra-acetic acid

\begin{tabular}{lcc} 
& $\begin{array}{c}\text { Umbilical cord blood } \\
(\mathrm{n}=20)\end{array}$ & $\begin{array}{c}\text { Peripheral blood } \\
(\mathrm{n}=9)\end{array}$ \\
\hline RBCs $\left(\mathrm{x} 10^{6} / \mu \mathrm{L}\right)$ & $5.08 \pm 0.15 \mathrm{a}$ & $7.76 \pm 0.26 \mathrm{~b}$ \\
$\mathrm{Hgb}(\mathrm{g} / \mathrm{dL})$ & $14.96 \pm 0.51$ & $15.63 \pm 0.3$ \\
$\mathrm{Hct}(\%)$ & $48.26 \pm 1.47$ & $48.36 \pm 1.41$ \\
$\mathrm{MCV}(\mathrm{fl})$ & $94.65 \pm 1.14 \mathrm{a}$ & $62.81 \pm 0.54 \mathrm{~b}$ \\
$\mathrm{MCHC}(\mathrm{g} / \mathrm{dL})$ & $31.15 \pm 0.24 \mathrm{a}$ & $32.41 \pm 0.5 \mathrm{~b}$
\end{tabular}

Means followed by distinct letters in the same row are different $(\mathrm{P}<0.05)$.

RBC: red blood cells; Hgb: hemoglobin; Hct: hematocrit; MCV: median corpuscular volume; MCHC: median corpuscular hemoglobin concentration.

Table 2. Total white blood cells, lymphocyte counts, lymphocyte subsets and CD4:CD8 rate (mean \pm SE) for umbilical cord blood from newborn puppies $(n=20)$ and peripheral blood from adult Beagles $(n=9)$, collected in ethylene diamine tetra-acetic acid

\begin{tabular}{llcc}
\hline & & $\begin{array}{c}\text { Umbilical cord blood } \\
(\mathrm{n}=20)\end{array}$ & $\begin{array}{c}\text { Peripheral blood } \\
(\mathrm{n}=9)\end{array}$ \\
\hline Total WBC & $\left(\mathrm{x} 10^{3} / \mu \mathrm{L}\right)$ & $11.47 \pm 1.02$ & $11.37 \pm 0.91$ \\
Lymphocytes & $(\%)$ & $26.6 \pm 1.48$ & $30.56 \pm 1.53$ \\
& $\left(\mathrm{x} 10^{3} / \mu \mathrm{L}\right)$ & $2.91 \pm 0.23$ & $3.54 \pm 0.36$ \\
$\mathrm{CD}^{+}$ & $(\%)$ & $31.8 \pm 2.1 \mathrm{a}$ & $63.67 \pm 2.14 \mathrm{~b}$ \\
& $(\mathrm{cels} / \mu \mathrm{L})$ & $893 \pm 62.7 \mathrm{a}$ & $2227.6 \pm 216 \mathrm{~b}$ \\
$\mathrm{CD} 4$ & $(\%)$ & $26.3 \pm 1.76 \mathrm{a}$ & $44.26 \pm 1.6 \mathrm{~b}$ \\
& $(\mathrm{cels} / \mu \mathrm{L})$ & $745 \pm 59.7 \mathrm{a}$ & $1549.4 \pm 163.42 \mathrm{~b}$ \\
$\mathrm{CD} 8$ & $(\%)$ & $3 \pm 0.25 \mathrm{a}$ & $19.54 \pm 1.82 \mathrm{~b}$ \\
& $(\mathrm{cels} / \mu \mathrm{L})$ & $86.35 \pm 6.29 \mathrm{a}$ & $665.22 \pm 68.24 \mathrm{~b}$ \\
$\mathrm{CD} 4: \mathrm{CD} 8$ & & $9.06 \pm 0.86 \mathrm{a}$ & $2.37 \pm 0.16 \mathrm{~b}$ \\
\hline
\end{tabular}

Means followed by distinct letters in the same row are different $(\mathrm{P}<0.05)$.

WBC: white blood cells.

The immune system of neonates is known for its immaturity, which is evidenced by the inability of building protection responses against pathogens (Delespesse et al., 1998). Although the development of the immune system of mammal fetus follows a consistent pattern, some phenomenon, like the $\mathrm{T}$ cells thymic sowing on the secondary lymphoid organs and the development of humoral immune responses, occur lately in dogs when compared to other domestic mammals (Tizard, 2002).

The smallest amount of $\mathrm{T}$ cells, verified in the UCB of neonate dogs, in comparison to adult dogs, suggests an immune component still immature, and can be explained by the maturation and expression of surface molecules after the birth (Schultz et al., 2000). The postnatal maturation of $\mathrm{T}$ cells is a complex phenomenon, which reflects the progressive exposition of the organism to several antibodies (Shu et al., 1994). The colonization of mature lymphocytes in the bone marrow starts between the second and the fourth weeks of life, postnatal, in a way that there is a very small amount of pan- $T$ lymphocytes in the bone marrow of neonate dogs (Faldyna et al., 2003).

Although the present trial has not accomplished the quantification of B lymphocytes, literature data asseverate that the percentage of these cells is high in the peripheral blood of newborn pupies and decreases with age (Faldyna et al., 2001). Studies accomplished with human UCB revealed a higher percentage of $\mathrm{B}$ cells and a lower percentage of $\mathrm{T}$ cells, the latter appearing to be primarily the result of a reduced percentage of cytotoxic T cells (Motley et al., 1996; Schultz et 
al., 2000). Also, immature T and B cells, as well as lymphocyte populations that are reduced or not found in adult samples, may contribute to the cellular composition of the umbilical cord blood of dogs.

The information related to the CD4:CD8 ratio are conflicting, and can be explained by the different methods used (Schultz et al., 2000). However, experimental trials showed that this ratio is high in the peripheral blood of newborn puppies and that it decreases with age (Faldyna et al., 2001; HogenEsch et al., 2004). In the present experiment, it was observed a CD4:CD8 ratio higher than that obtained in adult dogs $(\mathrm{P}<0.0001)$, agreeing with studies on human UCB (Dimitriou et al., 1998; Motley et al., 1996). The absolute superiority of the number of $\mathrm{CD}^{+}$cells in the UCB verified in this experiment may reflect a physiological tolerance mechanism of the immune system in the relationship between mother and fetus.

\section{ACKNOWLEDGMENTS}

The development of this trial was supported by FAPESP (Fundação de Amparo à Pesquisa do Estado de São Paulo) - process 03/03768-5. To the Flow Cytometry Laboratory at the Hemocenter Foundation of Ribeirão Preto/SP at the Faculdade de Medicina de Ribeirão Preto, Universidade de São Paulo for allowing the accomplishment of the cytofluorimetric evaluations. To the Instituto de Obstetrícia e Reprodução de Gatos e Cães (Prof. Dr. Vicenti Borelli from Hospital Veterinário Governador Laudo Natel - FCAV/UNESP, Jaboticabal, SP). To the Setor Nutricional de Cães FCAV/UNESP, Jaboticabal, SP. To GUABIMogiana Alimentos SA for allowing the collection of blood samples from the Beagles.

\section{REFERENCES}

BYRNE, K.M.; KIMA; H.W.; CHEWA, B.P. et al. A standardized gating technique for the generation of flow cytometry data for normal canine and normal feline blood lymphocytes. Vet. Immunol. Immunopathol., v.73, p.167-182, 2000.

DELESPESSE, G.; YANG, L.P.; OHSHIMA, V. et al. Maturation of human neonatal $\mathrm{CD}^{+}$and
$\mathrm{CD}^{+} \mathrm{T}$ lymphocytes into Th1/Th2 effectors. Vaccine, v.16, p.1415-1419, 1998.

DIMITRIOU, H.; MATSOUKA, C.; PERDIKOYANNI, C. et al. Phenotypic characteristics of cord blood hematopoietic cells. Leuk. Res., v.22, p.755-758, 1998.

FALDYNA, M.; LEVÁ, L.; KNOTIGOVÁ, P. et al. Lymphocyte subsets in peripheral blood of dogs - a flow cytometric study. Vet. Immunol. Immunopathol., v.82, p.23-37, 2003.

FALDYNA, M.; SINKORA, J.; KNOTIGOVA, $P$. et al. Flow cytometric analysis of bone marrow leukocytes in neonatal dogs. Vet. Immunol. Immunopathol., v.95, p.165-176, 2001.

HOGENESCH, H.; THOMPSON, S.; DUNHAM, A. et al. Effect of age on immune parameters and the immune response of dogs to vaccines: a cross-sectional study. Vet. Immunol. Immunopathol., v.94, p.77-85, 2004.

KATAOKA, A. Imunofenotipagem de linfócitos (pan-T, CD4 e CD8) e proteinograma sérico de cães com sorologia positiva para Erlichia canis. [Immunophenotyping of lymphocytes (pan-T, CD4, CD8) and seric protein profile of dogs presenting serological results for Erlichia canis.]. 2005. 57f. Tese (Doutorado) - Faculdade de Ciências Agrárias e Veterinárias, Universidade Estadual Paulista, Jaboticabal, SP.

LIN, S-J.; CHAO, H-C. Interleukin-15 enhances $\mathrm{CD}^{+} \mathrm{CD}^{4} 5 \mathrm{RA}^{+}$expression on umbilical cord blood mononuclear cells. Pediatr. Allergy Immunol., v.12, p.188-193, 2001.

LU, L.; SHEN, R-N.; BROXMEYER, H.E. Stem cells from bone marrow, umbilical cord blood and peripheral blood for clinical application: current status and future application. Crit. Rev. Oncol. Hematol., v.22, p.61-78, 1996.

MEINKOTH, J.H.; CLINKENBEARD, K.D. Normal hematology of the dog. In: FELDMAN, B.F.; ZINKL, J.G.; JAIN, N.C. (Ed.). Schalm's veterinary hematology. Philadelphia: Lippincott Williams \& Wilkins, 2000. p.1057-1063.

MOTLEY, D.; MEYER, M.; KING, R.A. et al. Determination of lymphocyte immunophenotypic values for normal full-term cord blood. Am. J. Clin. Pathol., v.105, p.38-43, 1996. 
NAKAGE, A.P.; CÁPUA, M.L.B.; SANTANA, A.E. Determinação do volume corpuscular médio (vcm), concentração de hemoglobina corpuscular média (CHCM) e porcentagem de reticulócitos no sangue do cordão umbilical de cães neonatos [Determination of $\mathrm{RBC}$ indices (MCV, MCHC) and reticulocytes counts in the umbilical cord blood of neonate dogs]. In: CONGRESSO BRASILEIRO DE MEDICINA VETERINÁRIA, 29., 2002, Gramado. Anais... Gramado, 2002. (CD-ROM).

NAKAGE, A.P.M.; CÁPUA, M.L.B.; GODOY, A.V. et al. Estudo das células sangüíneas do cordão umbilical de cães [Study on the hematology of the umbilical cord blood of dogs]. In: CONGRESSO BRASILEIRO DE CLÍNICOS VETERINÁRIOS DE PEQUENOS ANIMAIS, 20., 2003, Belo Horizonte. Anais.. Belo Horizonte, 2003(CD-ROM).

NAKAGE, A.P.M.; SANTANA, A.E.; CÁPUA, M.L.B. et al. Tipo de parto e a hematologia do cordão umbilical de cães. Cienc. Rural., v.35, p.377-380, 2005.
ROBINSON, K.L.; AYELLO, J.; HUGHES, R. et al. Ex vivo expansion, maturation and activation of umbilical cord blood-derived $\mathrm{T}$ lymphocytes with IL-2, IL-12, anti-CD3 and IL7: Potential for adoptive cellular immunotherapy post-umbilical cord blood transplantation. Exp. Hematol., v.30, p.145-251, 2002.

SCHULTZ, C.; REISS, I.; BUCSKY, P. et al. Maturational changes of lymphocyte surface antigens in human blood: Comparison between fetuses, neonates and adults. Biol. Neonate., v.78, p.77-82, 2000.

SZABOLCS, P.; PARK, K.D.; REESE, M. et al. Coexistent naive phenotype and higher cycling rate of cord blood $\mathrm{T}$ cells as compared to adult peripheral blood. Exp. Hematol., v.31, p.708714, 2003.

TIZARD, I.R. Imunologia Veterinária: Uma Introdução. São Paulo: Roca, 2002. 532p. 